\title{
ECOLOGICAL AND ENERGY ASPECTS OF USING THE COMBINED SOLAR COLLECTORS FOR LOW-ENERGY HOUSES
}

\author{
Stepan Shapoval ${ }^{1,}{ }^{*}$, Pavlo Shapoval ${ }^{2}$, Vasyl Zhelykh ${ }^{1}, 0$ stap Pona ${ }^{1}$, Nadiya Spodyniuk ${ }^{1}$, \\ Bogdan Gulai ${ }^{1}$, Olena Savchenko ${ }^{1}$, Khrystyna Myroniuk $^{1}$
}

https://doi.org/10.23939/chcht11.04.503

\begin{abstract}
The promising environmentally friendly solar heating systems are based on the combined solar collector, in which the absorber made of constructive material of low-energy house was described. The usage of the combined absorber with an external protection of lowenergy house ensures sufficient efficiency of combined solar collector and reduces its cost. Three-factor planning matrix with the factors interaction was developed. Analytical and graphical dependencies of efficiency of the combined solar collector with a transparent coating and without it on the angle of incidence and intensity of heat flow were shown. The efficiency of transparent coating which protects the absorber of solar collector was researched. Ecological effect of using the combined solar collector was calculated.
\end{abstract}

Keywords: combined solar collector, absorber, heat flow, environmentally friendly heating system.

\section{Introduction}

The current aggravation of issues related to the provision of energy population and industry of Ukraine, and the impact of the energy sector on the environment caused to the structural changes in the energy system of the country. That is why the development of the renewable energy sources is planned. The need to replace non-renewable energy sources is not only related to their depletion, but also to the danger of global scale. Burning coal, oil, gas and peat increase the amount of heat and $\mathrm{CO}_{2}$ which are released into the atmosphere and disturb the ecological balance.

\footnotetext{
${ }^{1}$ Department of Heat and Gas Supply, and Ventilation, Lviv Polytechnic National University,

12, S. Bandera St., 79013 Lviv, Ukraine

${ }^{2}$ Department of Analytical Chemistry, Lviv Polytechnic National University,

12, S. Bandera St., 79013 Lviv, Ukraine

* shapovalstepan@mail.ru

(C) Shapoval S., Shapoval P., Zhelykh V., Pona O., Spodyniuk N., Gulai B., Savchenko O., Myroniuk K., 2017
}

Industrial and commercial sectors in Ukraine tend to saving technologies, and the rate of using the new environmentally friendly ways of getting energy is insignificant. Therefore, the introduction of alternative energy sources and eco-construction development are a key issue today. Low-energy houses or passive houses are energy efficient building standards which create comfortable living conditions and carry a minimum negative impact on the environment. The use of solar energy for heat and electricity needs is the most promising area of environmental and energy development. Using about $2 \%$ of the amount of solar energy could provide all global energy needs today that will have a significant positive environmental impact. The collected solar radiation replace the energy generated using "dirty" technologies. This is the main environmental impact of solar energy.

Solar systems do not affect the thermal regime of the planet due to a small proportion of solar energy use. But it returns after conversion into the environment as heat. The main negative impact of solar power plants on the environment is indirect - these are the processes which are associated with the production of new materials and coatings for solar power plants equipment to increase their efficiency.

Currently, there is a significant shortage of energy in almost all areas of the economy. Status of implementation of ecological solar heating systems in utilities needs the substantial improvement $[1,2,5,10]$. The energy-fencing structures, such as the roofs and external walls of construction projects (residential, public, administrative, etc.), as well as the elements of industrial facilities surfaces (freezers, refrigerators, dryers, etc.), have been developed [3, 4]. Such designs allow to utilize hot water supply, air conditioning and industrial heat energy of solar radiation, the outside heat and exhaust air, as well as to implement the functions outside release excess heat and heat storage regulation $[3,6]$. The wall solar collectors that simultaneously act as fencing structures are widely used [4, 7-9]. However, these systems have several disadvantages, among which are: relatively high cost, high dependence of heat generated from the period of the day, and so on. 
Therefore, it is proposed to use the solar collector combined with structural building material, in which absorber is made of roofing material of the building or of the structural building material. Efficiency of the combined solar collector in the presence and absence of a glass coating is researched. The economic and environmental effects of using the combined solar collector are calculated.

The aim of this work is the study of environmentally friendly heating system based on solar collector combined with elements of energy efficient house which is designed with tubes located under the absorber in the gravitational system.

\section{Experimental}

\subsection{Description of the Experimental Setup}

Experimental studies were performed on the facility, which consisted of combined solar collector, tank battery, source of radiation and measuring devices. The experimental setup is shown in Fig. 1.

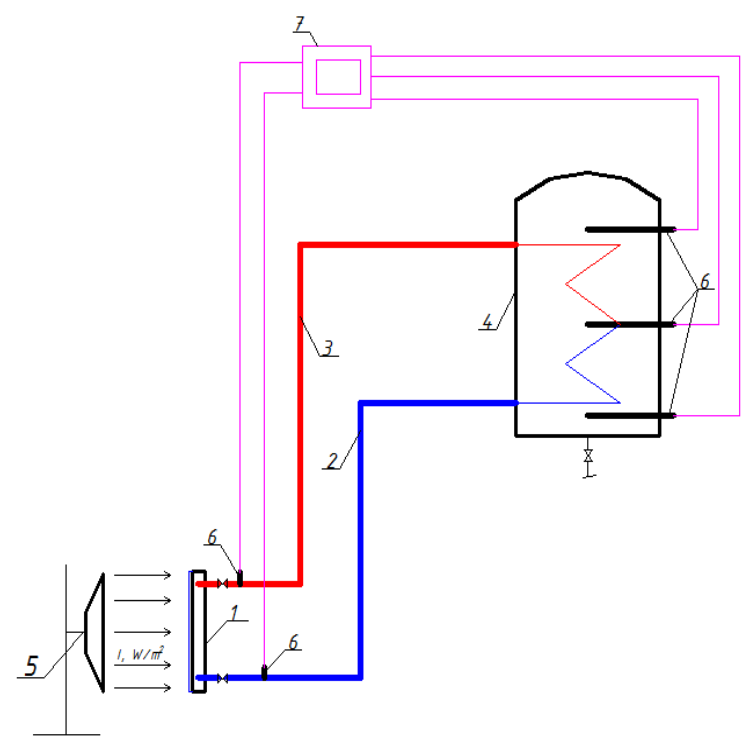

Fig. 1. The experimental setup: combined solar collector (1); reverse pipeline (2); feeding pipeline (3); tank battery (4); radiation source (5); thermometer (6) and display (7)
Combined solar collector is based on the task to improve the flat solar collector, its energy and environmental performance. Taking into account that heat absorption material of solar collector is at the same time the roofing material of the building, it helps to reduce costs, increase flexibility and environmental efficiency of the solar collector. Transparent coating, which is made of glass, significantly reduces the solar collector heat, as in the space between the glass and roofing material there is a layer of air. Combined solar collector can effectively use the heat of a roofing material of the building.

Sunlight falls on the outer surface of the corrugated outer coating, made of roofing material. The inner surface is coated with a selective layer material made of black chrome, which ensures maximum absorption of solar heat at the minimum level of reflection of sunlight back into the atmosphere. The result of this is heating. Heat is transferred by the tubes loop circulation, in which coolant is circulated. Due to the temperature and density differences, the coolant circulation is created in the area of inlet and outlet sockets. The heated coolant is supplied to the consumer. Insulating layer and transparent top layer reduce the heat loss.

The temperature of water was measured at three points of the system (at the outlet of the combined solar collector, at the inlet of the combined solar collector, and in the tank-battery) by thermometers.

The results of experimental studies of the combined solar collector with the transparent coating in gravitational solar heating system were obtained at tube diameter $d=10 \mathrm{~mm}$ and the distance between the tubes $l=10 \mathrm{~mm}$. Thermal radiators, which were used, could give power of $1000 \mathrm{~W} / \mathrm{m}^{2}$.

Every time before the experiment the system was filled with a portion of fresh water. We checked the the system hermiticity under the operating pressure. Pipelines with rubber hoses were insulated to minimize heat loss during the experimental studies. Storage tank was insulated with mineral wool of $100 \mathrm{~mm}$ thickness and coated with a heat-eliminating coating.

\subsection{Planning of the Experiment}

The following factors were chosen for the experiment: azimuth turning angle of the solar collector, the slope angle of the collector and the heat flow intensity. Table 1 presents the levels of factors and variation intervals.

Table 1

The levels of factors and variation intervals

\begin{tabular}{|c|c|c|c|c|c|}
\hline Factor name & \multirow{2}{*}{ Code } & \multicolumn{3}{|c|}{ Factor levels } & \multirow{2}{*}{ Variation } \\
\cline { 3 - 5 } & & -1 & 0 & +1 & \\
\hline Azimuth turning angle of the solar collector $\alpha,^{\mathbf{o}}$ & $x_{1}$ & 30 & 60 & 90 & 60 \\
\hline Slope angle of the solar collector $\beta,^{\circ}$ & $x_{2}$ & 30 & 60 & 90 & 60 \\
\hline Heat flow intensity $I, \mathrm{~W} / \mathrm{m}^{2}$ & $x_{3}$ & 300 & 600 & 900 & 600 \\
\hline
\end{tabular}


We developed the three-factor planning matrix taking into account the factors interaction. The optimization parameter was the efficiency coefficient of the combined solar collector without the transparent coating $K_{e f 1}$, and the efficiency coefficient of the combined solar collector with the transparent coating $K_{e f 2}$. It shows how the change of the angle of incidence influences the efficiency of the solar collector.

The coefficient of efficiency of the combined solar collector $K_{e f}$ is determined by the formula:

$$
K_{e f}=\frac{y_{i}}{y_{s t}}
$$

where $y_{s t}-$ the heat energy received by the combined solar collector at the angles of incidence $\alpha=90^{\circ}, \beta=90^{\circ}$ and heat flow intensity $I=900 \mathrm{~W} / \mathrm{m}^{2} ; y_{i}$ - the heat energy received by the combined solar collector at other values of angle of incidence and heat flow intensity.

\section{Results and Discussion}

On the basis of experimental data (Table 2) we get the following equation of regression:

$$
\begin{gathered}
K_{e f 1}=0.80+0.027 x_{1}+0.0546 x_{2}+0.054 x_{3}+ \\
+0.001 x_{2} x_{3}+0.001 x_{1} x_{2} x_{3}
\end{gathered}
$$

After analyzing the coefficients of regression, we can conclude that slope angle (factor $x_{2}$ ) and heat flow intensity (factor $x_{3}$ ) have the significant impact on the efficiency of the combined solar collector; the azimuth turning angle (factor $x_{1}$ ) affects it slightly. The increase in all factors value increases the solar system efficiency.

The results of experimental studies are presented in graphics forms (Figs. 2, 3).

The experimental studies show that by changing the angles of incidence $\alpha$ and $\beta$ from $90^{\circ}$ to $30^{\circ}$ the efficiency of the combined solar collector without the transparent coating is reduced by $67 \%$, the collector with the transparent coating - by $32 \%$, the conventional flat solar collectors - by $60 \%$. The combined solar collector with the transparent coating shows the best results.

Based on the experiments we got empirical equations which show the dependence of azimuth turning angle of the combined solar collector $\alpha$, the slope angle $\beta$, the heat flow intensity $I$ and coefficients of efficiency $K_{e f 1}$ and $K_{e f 2}$.

$$
\begin{aligned}
K_{\text {ef } 1}= & ((513+0.458 I)+(22+0.038 I) \cdot \beta+12 \cdot \alpha+ \\
& \left.+\left(-0.019+6.389 \cdot 10^{-5} \cdot I\right) \cdot \beta \cdot \alpha\right) \cdot 10^{-4} \\
K_{\text {ef } 2}= & ((3625+3 I)+(37-0.022 I) \cdot \beta+(27-0.025 I) \cdot \alpha+ \\
& \left.+\left(-0.233+5.556 \cdot 10^{-4} \cdot I\right) \cdot \beta \cdot \alpha\right) \cdot 10^{-4}
\end{aligned}
$$

\begin{tabular}{|c|c|c|c|c|c|c|c|c|c|c|}
\hline No. & $x_{0}$ & $x_{1}$ & $x_{2}$ & $x_{3}$ & $x_{1} x_{2}$ & $x_{1} x_{3}$ & $x_{2} x_{3}$ & $x_{1} x_{2} x_{3}$ & $K_{e f 1}$ & $K_{e f 2}$ \\
\hline 1 & + & - & - & - & + & + & + & - & 0.20 & 0.58 \\
\hline 2 & + & 0 & - & - & 0 & 0 & + & 0 & 0.27 & 0.64 \\
\hline 3 & + & + & - & - & - & - & + & + & 0.33 & 0.68 \\
\hline 4 & + & - & 0 & - & 0 & + & 0 & 0 & 0.33 & 0.68 \\
\hline 5 & + & 0 & 0 & - & 0 & 0 & 0 & 0 & 0.40 & 0.72 \\
\hline 6 & + & + & 0 & - & 0 & - & 0 & 0 & 0.47 & 0.75 \\
\hline 7 & + & - & + & - & - & + & - & + & 0.47 & 0.75 \\
\hline 8 & + & 0 & + & - & 0 & 0 & - & 0 & 0.53 & 0.80 \\
\hline 9 & + & + & + & - & + & - & - & - & $0 ., 60$ & 0.83 \\
\hline 10 & + & - & - & 0 & + & 0 & 0 & 0 & 0.27 & 0.68 \\
\hline 11 & + & 0 & - & 0 & 0 & 0 & 0 & 0 & 0.33 & 0.72 \\
\hline 12 & + & + & - & 0 & - & 0 & 0 & 0 & 0.40 & 0.75 \\
\hline 13 & + & - & 0 & 0 & 0 & 0 & 0 & 0 & 0.40 & 0.75 \\
\hline 14 & + & 0 & 0 & 0 & 0 & 0 & 0 & 0 & 0.53 & 0.80 \\
\hline 15 & + & + & 0 & 0 & 0 & 0 & 0 & 0 & 0.60 & 0.83 \\
\hline 16 & + & - & + & 0 & - & 0 & 0 & 0 & 0.60 & 0.83 \\
\hline 17 & + & 0 & + & 0 & 0 & 0 & 0 & 0 & 0.67 & 0.88 \\
\hline 18 & + & + & + & 0 & + & 0 & 0 & 0 & 0.73 & 0.92 \\
\hline 19 & + & - & - & + & + & - & - & + & 0.33 & 0.75 \\
\hline 20 & + & 0 & - & + & 0 & 0 & - & 0 & 0.40 & 0.80 \\
\hline 21 & + & + & - & + & - & + & - & - & 0.47 & 0.83 \\
\hline 22 & + & - & 0 & + & 0 & - & 0 & 0 & 0.47 & 0.83 \\
\hline 23 & + & 0 & 0 & + & 0 & 0 & 0 & 0 & 0.60 & 0.88 \\
\hline 24 & + & + & 0 & + & 0 & + & 0 & 0 & 0.73 & 0.92 \\
\hline 25 & + & - & + & + & - & - & + & - & 0.73 & 0.92 \\
\hline 26 & + & 0 & + & + & 0 & 0 & + & 0 & 0.80 & 0.97 \\
\hline 27 & + & + & + & + & + & + & + & + & 1.00 & 1.00 \\
\hline
\end{tabular}

Table 2

Matrix of experimental design 


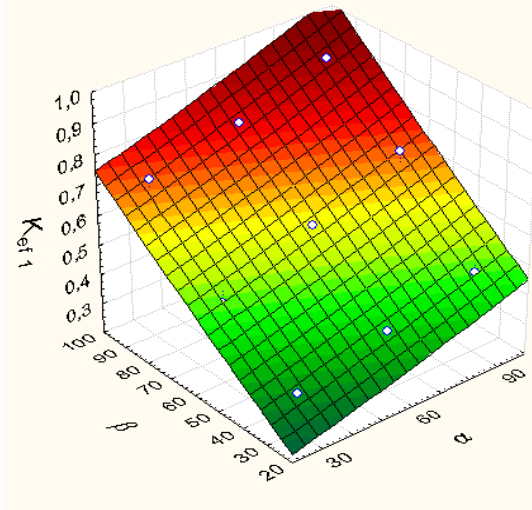

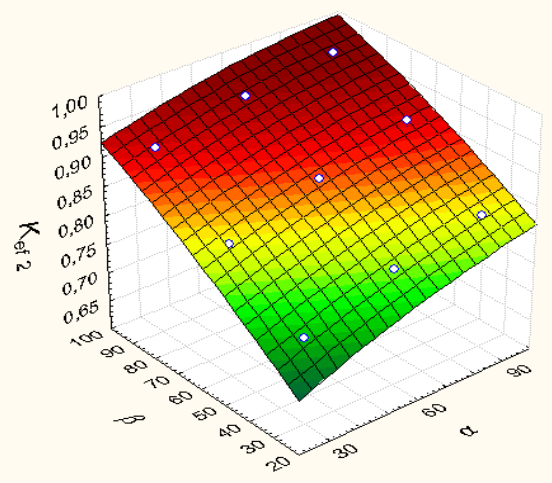

Fig. 3. The efficiency of the combined solar collector with the transparent coating in gravitational heating system at the heat flow intensity of $900 \mathrm{~W} / \mathrm{m}^{2}$

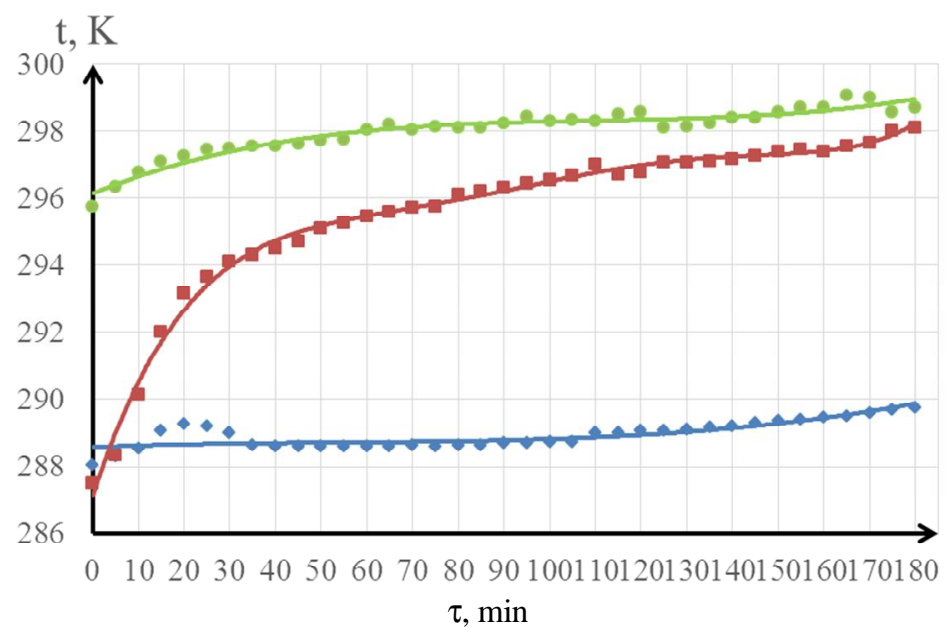

Fig. 4. The results of experimental studies of the combined solar collector: $t_{\text {in }}$ - temperature of water at the inlet of the solar collector, $\mathrm{K}(\diamond)$; $t_{\text {out }}-$ temperature of water at the outlet of the solar collector, $\mathrm{K}(<)$;

$t_{a v}-$ the average temperature of air near the experimental setup, $\mathrm{K}(\bullet)$
The results of the temperature measurements of the coolant at the inlet and outlet of the combined solar collector and averaged temperature of air near the experimental setup are presented in a graphical form in Fig. 4.

We observe a gradual increase of water temperature throughout the experiment. The temperature of water at the outlet of the combined solar collector has reached $298.4 \mathrm{~K}$, indicating its effective work.

It is reasonable to analyze the change of efficiency of the combined solar collector during the experiment.

The efficiency of the combined solar collector is determined by the formula:

$$
\eta_{s c}=\frac{Q_{s c}}{I} \cdot 100 \%
$$

where $Q_{s c}$ - the specific instantaneous heat power of the combined solar collector, $\mathrm{W} / \mathrm{m}^{2} ; I-$ the intensity of heat source, $\mathrm{W} / \mathrm{m}^{2}$.

$$
Q_{s c}=G \cdot c \cdot\left(t_{\text {out }}-t_{\text {in }}\right)
$$

where $G$ - the specific consumption of the coolant, $\mathrm{kg} /\left(\mathrm{s} \cdot \mathrm{m}^{2}\right) ; c-$ specific heat capacity of the coolant, $\mathrm{J} /(\mathrm{kg} \cdot \mathrm{K}) ; t_{\text {out }}, t_{\text {in }}$ - the temperatures of the coolant at the inlet and outlet of the combined solar collector, $\mathrm{K}$.

Fig. 5 shows the dependence of the specific instantaneous heat power of the combined solar collector at the time of exposure. We observe a sharp increase of the specific instantaneous heat power and at the end of experiment it is equal to $3100 \mathrm{~W} / \mathrm{m}^{2}$.

Fig. 6 shows the growth of efficiency of the combined solar collector to the $90^{\text {th }}$ minute, which is $60 \%$. Then we do not observe any significant changes and the efficiency remains at the same level: 53-60\%.

It is advisable to analyze the efficiency of the solar system relative to the amount of solar heat energy received by the tank battery. Fig. 7 shows the change of water temperature in the tank battery during the experiment. The gradual heating of water in the tankbattery is observed throughout the experiment at all levels $\left(t_{b o x 1}, t_{b o x 2}, t_{b o x 3}\right)$. 
To substantiate the expediency of the combined solar collector usage the cost of alternative energy and usual heat sources should be compared. The calculation was performed for the two-store building located in Lviv, where 4 people live.

The price of natural gas, provided that natural gas consumption volume does not exceed $200 \mathrm{~m}^{3}$ per month, is $7.200 \mathrm{UAH}$ per $1 \mathrm{~m}^{3}$.

Given the constant load on the hot water system for a year, we can get the total annual consumption of natural gas $Q_{y}$, which amounts to $1.039 \mathrm{~m}^{3} /$ year.

Total annual price for gas $P$ spent for the needs of hot water determined by the formula, UAH/year:

$$
P=Q_{y} \cdot 7.200
$$

where $7.200 \mathrm{UAH} / \mathrm{m}^{3}$ - the price of natural gas,

Cost savings, calculated by the formula, UAH/year:

$$
h=\frac{\eta_{s c}}{100} \cdot P
$$

where $\eta_{s c}$ - efficiency of combined solar collector, $\%$.

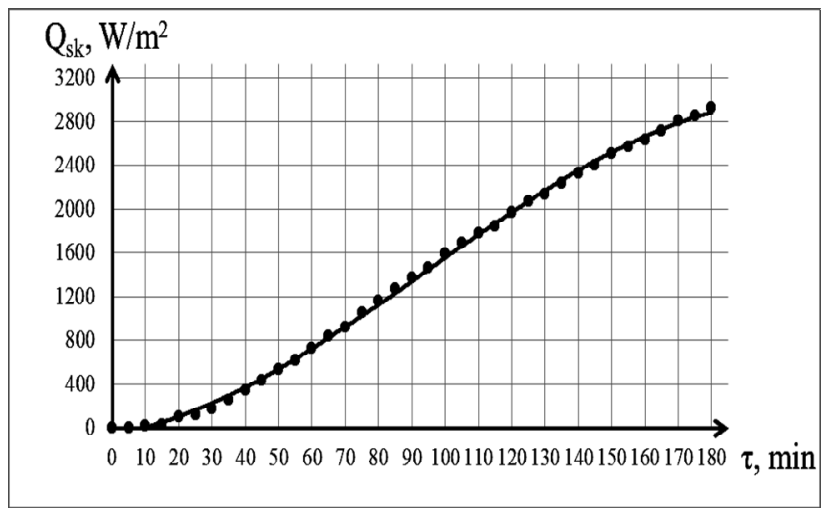

Fig. 5. Change of the specific instantaneous heat power of the combined solar collector depending on the exposure time

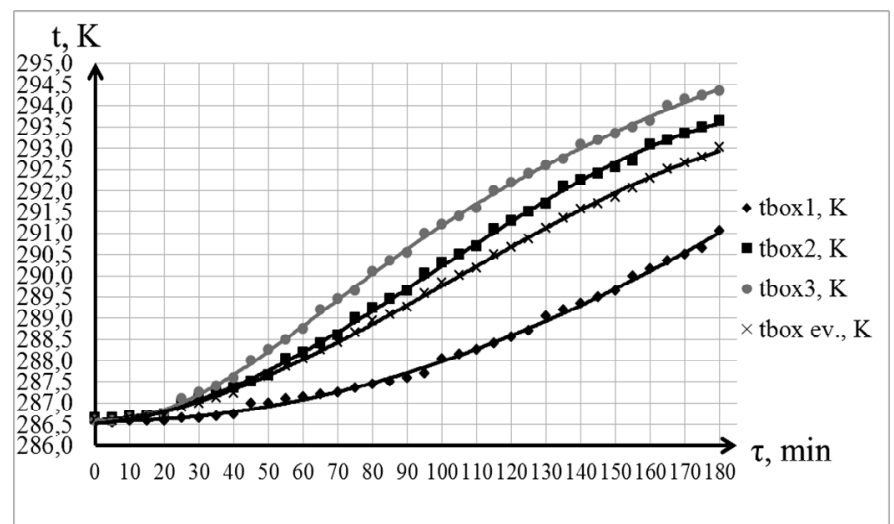

Fig. 7. Change of water temperature in the tank-battery: $t_{b o x l}, t_{b o x 2}$, $t_{b o x 3}-$ temperatures of water at height of the tank-battery, $\mathrm{K} ; t_{\text {box.ev }}$. average temperature of water in the tank-battery, $\mathrm{K}$
If we know the required amount of other types of energy sources for heating system and cost savings we may calculate the energy savings of the combined solar collector [9].

Fig. 8 shows the energy savings of the combined solar collector, which allows to obtain a positive environmental effect. The combined solar collector is efficient not only in money terms but also in terms of the different types of energy resources. It can save up to 670 $\mathrm{UAH} /$ year or $\sim 1614 \mathrm{kWh}$.

The combustion of $1 \mathrm{~m}^{3}$ of gas releases about $2 \mathrm{~kg}$ of $\mathrm{CO}_{2}$, which significantly pollutes the environment [7]. Due to the implementation of the combined solar collector the saved amount of natural gas will be $1039-623.4=$ $=415.6 \mathrm{~m}^{3} /$ year. Amount of carbon monoxide, which is released into the atmosphere will be $40 \%$ less than using the traditional energy sources, that confirms the positive ecological effects of the proposed system on the environment.

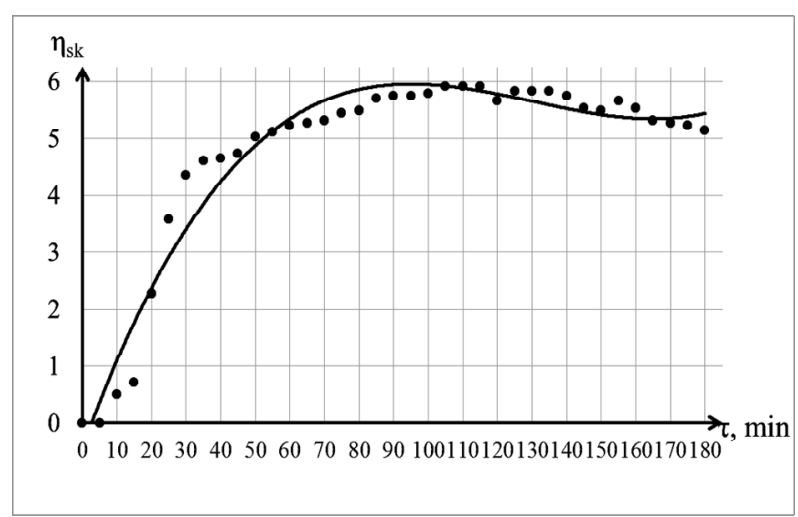

Fig. 6. Change of the efficiency of the combined solar collector depending on the exposure time

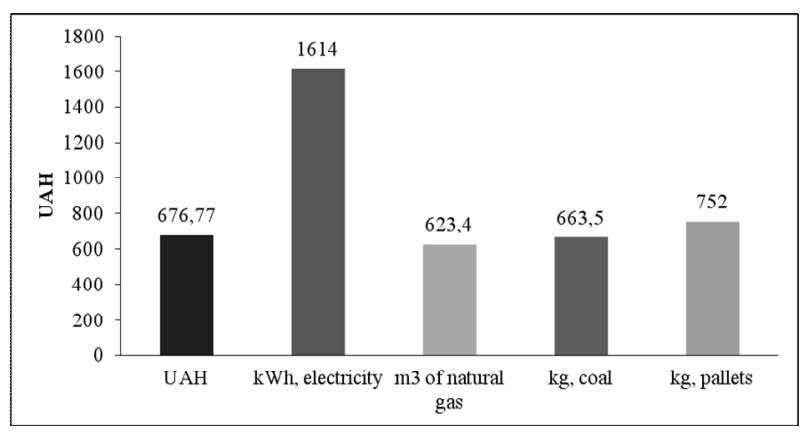

Fig. 8. Saving of energy resources by the combined solar collector 


\section{Conclusions}

The usage of the combined solar collector in the solar heating systems for low-energy house can significantly reduces the cost of solar systems and improves the ecological environment. An important factor which influences the efficiency of the combined solar collector is the presence of a transparent coating. Analytical and graphical dependencies of efficiency of the combined solar collector with a transparent coating and without it on the angle of incidence and intensity of heat flow were received. The efficiency of the combined solar collector with the transparent coating is $35 \%$ higher than collector without it. The dependences of the heat amount, collector efficiency and heating temperature on exposure time were established. The efficiency of the combined solar collector reaches a value of $60 \%$, indicating its effective work. The usage of the combined solar collector allows to reduce harmful emissions by $40 \%$ and thus provides a significant environmental impact.

\section{References}

[1] Mysak Y., Voznyak O., Datsko O., Shapoval S.: Sonyachna Enerhetyka: Teoriya ta Praktyka. Vyd-vo Lviv Polytechnic, Lviv 2014.

[2] Duffie J., Beckman A.: Solar Engineering of Thermal Processes, $2^{\text {nd }}$ edn. Wiley-Intersci. Publ., New York 1980.

[3] Strashko V.: Ecotekhnolohii i Resursozberezheniya, 2005, 6, 68.

[4] Freris L.: Renewable Energy in Power Systems. JohnWiley\&Sons, New York 2008.

[5] Hazami M., Kooli S., Lazaar M. et al.: Am. J. Environ. Sci., $2005,1,270$
[6] Hantula R.: Science in the Real World: How Do Solar Panels Work? Chelsea House Publ., New York 2010.

[7] Maczulak A.: Renewable energy: Sources and Methods. Info base Publ., New York 2010.

[8] Mamlok R., Nijmeh S., Abdallah S.: Inform. Technol. J., 2006, 5, 1083.

[9] Lorenz P., Pinner D., Seitz T.: The Economics of Solar Power. The Mc Kinsey Quarterly, NY 2008.

[10] Guminilovych R., Shapoval P., Yatchyshyn I., Shapoval S.: Chem. Chem. Technol., 2015, 9, 287.

Received: M ay 23, 2016 / Revised: M arch 03, 2017 / Accepted: M ay 22, 2017

\section{ЕКОЛОГІЧНІ ТА ЕНЕРГЕТИЧНІ АСПЕКТИ ВИКОРИСТАННЯ КОМБІНОВАНИХ ГЕЛІОКОЛЕКТОРІВ ДЛЯ ЕКОБУДИНКІВ}

Анотація. Описано перспективні екологічно безпечні системи сонячного теплопостачання на основі комбінованого геліоколектора, теплопоглинач якого виконаний із конструктивного матеріалу екобудинків. Показано, щзо використання комбінованого теплопоглинача із зовнішнім захищенням екобудинку дає можсливість забезпечити достатню ефективність комбінованого геліоколектора та зменшити його вартість. Розроблено трифакторну матрицю із врахуванням взаємовпливу всіх чинників. Приведено аналітичні та графічні залежності ефективності комбінованого геліоколектора з прозорим покриттям та без нього від кутів падіння теплового потоку та його інтенсивності. Досліджено ефективність захисту теплопоглинача геліоколектора прозорим покриттям. Розраховано екологічний ефект від використання комбінованого геліоколектора.

Ключові слова: комбінований геліоколектор, теплопоглинач, тепловий потік, екологічно безпечна система теплопостачання. 